\title{
Lessons Learned in Teaching Heat Transfer with a Flipped Classroom
}

\section{Dr. Francis Wessling, University of Alabama, Huntsville}

Professor, Mechanical and Aerospace Engineering, The University of Alabama in Huntsville, 1985 present Former Chair of the Department (1999 - 2003, 2007) Fellow, ASME Associate Director, Consortium for Materials Development in Space 1985 - 1999 Professor, Mechanical Engineering, University of New Mexico, 1967 - 1979

\section{Dr. Sarah A Roller, University of Alabama in Huntsville}

Sarah A. Roller is an Assistant Professor in Mathematics Education at the University of Alabama in Huntsville. She received her Ph.D. in curriculum, teaching, and educational policy from Michigan State University. Her research interests include teacher preparation and mentoring practices, research-based instructional strategies for teaching mathematics and STEM education, and teacher development. 


\title{
Lessons Learned and Adjustments Made while
}

\section{Teaching Heat Transfer with a Flipped Classroom}

\begin{abstract}
With increasing amounts of technology readily available, many secondary and post-secondary instructors have begun utilizing a flipped classroom approach to support student learning. Described broadly, this approach "flips" traditional lectures outside the classroom with video technology and uses class time to engage students in problem solving that is facilitated by the instructor. This paper describes students' perceptions and reactions to one college professor's attempt to utilize a flipped classroom model with his engineering students. Further discussion is offered in the paper analyzing the ways in which the course structure evolved and the lessons learned.
\end{abstract}

Introduction

The "flipped class" has several variations. ${ }^{1}$ Flipped classrooms are generally structured to have pre-recorded presentations of the course materials followed by in-class activities. The expectation within flipped classrooms is for students to view and study the material prior to class. For some flipped classes, students complete in-class quizzes before working together on assigned class problems. ${ }^{2}$ For other flipped classes, the students complete pre-class quizzes after watching the online lecture at home. This was followed by class activities. ${ }^{3}$ Another flipped class adaptation has included adding an on-line discussion before class, which allowed instructors to formatively assess student learning and to provide in-class review sessions before the other classroom activities. In this case, an online quiz was administered toward the end of the online lecture, for which students earned participation points. ${ }^{4}$ In this study, the first author used recorded class lectures from a previous semester for course content and had students present their individual homework solutions in class. The presentation and accuracy of these solutions were graded in real time.

The flipped classroom in this study was a senior level heat transfer class of 65 students, which also included a laboratory component to reinforce the learning of the classroom. The professor, who was experienced teaching the course, had become concerned about the level of learning and perceived lack of engagement on the part of the students. The flipped class method seemed to be a possible solution, since it had given indications of better understanding of course material. ${ }^{5}$ Because this was a senior level class, the professor recognized that when the students graduated in a few months, they would need to be able to take initiative and have knowledge to apply to their heat transfer challenges at their workplace. The professor hoped to use the class to groom the students for responsible positions at their workplaces upon graduation as well as have them 
learn heat transfer. The flipped classroom would give them opportunities to speak to a large group and to defend their ideas. The intent was to increase learning and to make the students more accountable. This flipped class differed from other flipped classes because the students were not only responsible for viewing the online lectures and course materials, but were also expected to complete homework problems before coming to class. Flipped classes usually use the class time for working the homework with the professor's assistance. Having students solve problems before coming to class was done with the intent of having the students transition from relying on the professor for learning to self-sufficient problem solving.

The first author had many discussions with Dr. Sharpe ${ }^{6}$ during the adaptation of the technique to a senior level engineering heat transfer class. She had used a flipped class technique at the University of Virginia, Darden School of Business in a master level class in entrepreneurship. That class consisted of groups of students meeting with clients to help them to develop a business. There were interactions among her, the clients, and the students. These interactions resulted in class participation to be heavily (20\%) weighted in the final grade.

Another engineering professor in the first author's department who taught a Fluid Mechanics class at his university had tried the flipped classroom approach previously. Unfortunately, that experiment was terminated midway through the semester because of student discontent, and reverted back to the standard lecture method. This type of push back from students was predicted by the business school professor and others ${ }^{7}$ who stated, "The students will push back but will come around.” It was for this reason that the engineering professor encouraged the first author not to quit when students pushed back.

Initial Flipped Course Structure

The heat transfer course was structured so that students would view online videos of recorded lectures of a previous semester course. These online lectures were 80 minutes long and were the standard lectures that students would have had if the professor lectured in the standard manner. In addition to these videos, the professor made short videos (five to ten minutes) focused on basic concepts. Shifting the lectures outside of the classroom then freed up the class time for students to present their solutions to assigned homework problems. Homework was not otherwise collected nor graded because the students had access to online solution manuals.

In order to motivate the students to complete their homework and participate in class, student's participation was part of their total class grade. This was modeled after the business school. A student's participation grade was based on class attendance and the quality of the responses given when the student was called on in class. Additionally, in an effort to encourage class attendance, students would lose a letter grade for every two unexcused absences. As a result, they could fail the course while having a perfect score on each exam.

Homework presenters were selected by random drawing with replacement of student names from a bag. A definite format for the homework solution was prescribed so that the presentations 
would be organized. The format was taken from a textbook ${ }^{8}$ and consists of seven logical steps. This was to help the student stay on track during the presentation. The student reported from her/his desk and explained to the class the solution method. The professor recorded on the board the pertinent points of the solution, while also encouraging explanation by asking questions.

The professor asked the whole class for their insights to each question in order to encourage discussion and to gain more understanding among the whole class. The professor guided the presenter and kept her/him on track, making sure the question was eventually answered correctly. During the presentation, the students were free to ask the presenter about questions related to the problem. The professor referred questions directed to him to the presenter or to the class members, who were also encouraged to share their thoughts. The professor rated the presenter on the quality of the presentation. Others were rated on the quality of their insights to the problem. These ratings were used for class participation points.

\section{Participation Points}

Because part of the goal in flipping the heat transfer classroom was to increase student participation, one of the challenges was figuring out how to record student participation points. The first half of the semester the random draw with replacement seemed to be biased. This may have been because the names were on cardboard squares and mixing may have been inadequate. In addition, more students on the left side of the room, as viewed from student seats, picked up more voluntary (as opposed to called upon) point opportunities than the other side. To even out the disparity of opportunity, two separate name repositories were used for drawing names. Those on the neglected side of the room were deliberately drawn. This tended to even out the opportunities. Then, the professor reviewed who had the least participation opportunities. A portion of the problems was assigned for those specific students to discuss. Five points were awarded for an excellent presentation, three points for a mediocre presentation, and no points for being unprepared. Their written solutions were not checked.

Overall, not every student would be rated every class period, but each student would have ample opportunities to participate over the semester. Generally, 15\% to 20\% (nine to 12) students received participation points each class session. The points were totaled at the end of the semester and curved to eight percent of their final grade.

It was around mid-semester when students were informed via email about their participation points. Then, students realized they were frittering away almost a full letter grade by not being prepared to present their homework in class. Originally, students had been given the weighting of the grade distribution in the course syllabus, but it seemed many students had not read it closely. After realizing the importance of the participation points, many students were very willing to respond to the professor's request for volunteers. The professor had to ignore some students in order to give the more reticent ones opportunities, and began pre-selecting presenters 
before class to even out the participation opportunities and to not lose instructional time by drawing names in class.

Student Reactions to Initial Structure and Professor Responses

Objections to the flipped classroom approach were immediate. The students voiced that the homework required in this flipped class approach exceeded the amount of time that students could devote to the class, particularly because students were being expected to watch full lectures (three hours a week) in addition to completing the homework problems outside of class. Because the lecture was recorded, students criticized that they were teaching themselves, versus having an expert readily available for questions. They also complained that they did not want to be held publically accountable for doing the homework. Some students further stated that they found the classroom discussion to be confusing because they were unsure about the accuracy of the presenter's response, even though the professor summarized the correct concepts at the end of each discussion. Beyond the course structure, the students also criticized that the number of office hours was inadequate, even though they exceeded the university recommended amount of two hours per week for each lecture class taught.

Being responsive to his students, and understanding that each homework problem took between twenty to forty minutes to solve, the professor reduced the number of problems from four to three. He also encouraged them to work together on the homework. The statistics from the online video system demonstrated that fewer than $10 \%$ of the students were watching the video lectures, and many of these were only watching a few minutes. Additionally, the professor did provide shorter (5 to 10 minute) videos on selected topics, but these too were not viewed by more than $10 \%$ of the students. Allowing the class to evolve around the concept of career development, the professor believed that life-long learning required time expenditure. In regard to presenter's responses sometimes having inaccuracies, the professor responded that when one works for a company, some discussions might have wrong ideas put forward, and that it would be the individual's professional responsibility to follow along and sort out the scientifically correct and incorrect items. Individuals would also need to ask questions to add clarity to the discussion, versus tune out which could be interpreted as a lack of interest in the company's challenges.

Additionally, the professor also increased the number of office hours from 3 to 4.5 per week. Participation points were given for using the office hours, if the student came in with pertinent questions and not just to chat. The students however rarely used the available daytime office hours, and later admitted that this was because they often did not start the homework until the night before it was due.

Unsatisfied with these minor changes, the students took their frustrations to a higher level. The chair of the department and the dean's office reported that the students were complaining, although no specifics were given to the professor. The administration worried that the students 
might complain to the Accreditation Board for Engineering and Technology (ABET) evaluators when they reviewed the college, which had potential to reflect negatively on the department. The professor responded that only $10 \%$ of the students had voiced concerns, and that did not seem like an unreasonable number.

Seven weeks into the semester, several students wrote a critically reflective letter outlining their concerns about the flipped classroom structure. This was addressed to the chair of the department, the associate dean of the college, the dean of the college and the president of the university. The concerns were: 1 ) no notice prior to registration was given that the class would be flipped, 2) the online videos allowed no face-to-face interactions among the professor and students in a classroom setting, 3) the students felt they were teaching themselves versus being taught by an experienced professor, 4) the students felt they were taking an online class, 5) the amount of time required for a class of this type was considerably more than a standard lecture class. The students stated that they were not complaining about the professor but about the issues they were experiencing with the flipped classroom structure.

The administration's response stated that the professor had improved teaching as a goal and that he was free to experiment with teaching methods. The professor then held a class discussion about the "flipped" teaching method.

\section{Course Revisions}

The class discussion was polite and respectful. The professor complimented the students for writing such a thoughtful and respectful letter explaining their concerns. After about twenty minutes of open discussion, the students recognized that the professor was not willing to go back to the standard lecture method. One student suggested a compromise, in which the student presentations would be held for one hour of the class and the professor would lecture on the next subject matter for the last thirty minutes. The compromise provided the students with more opportunities for live dialogue with the professor during the class, which had been one of their main concerns, while also maintaining the presentation portion of class which the professor valued. Thus, this compromise was agreeable to all and adopted.

After the class discussion, the professor reexamined his participation and attendance policies, since shortening the time for student presentations also shortened the opportunity for students to gain participation points. Consequently, the homework problems were divided into parts so that more students could present in the shorter period of time, while also allowing enough time for the professor to assess the student's work. The professor decided to remove the attendance policy that resulted in a loss of a letter grade for every two unexcused absences, feeling it was punitive in nature, and also after discovering that the attendance sheet was being signed on behalf of absent classmates. Furthermore, the professor invited students at mid semester to complete an anonymous survey about their background and activities. The results of this survey are discussed in the next section. 
Incidentally, the students did have an opportunity to speak with the ABET evaluators. Two faculty members in that meeting told the professor that the students reported appreciating what the professor was trying to do, and also complimented him about the approach he took in working with the students to improve the situation. They liked that he was very open to their suggestions and treated them with respect. Some students even admitted that they liked the flipped classroom.

Mid Semester Survey Results

The professor realized that he had very little knowledge of the constraints on his students. So he created an anonymous survey about their life situations. The survey covered student demographics and student activities. The University administration deemed that this did not require Institutional Review Board action. The results can be seen in Table 1 and Table 2. Eighty-eight percent of the students responded (57 respondents). The results of the survey showed the busy schedules of many of the students. The mean, variance, and standard deviation are related to the answer choice. For example, the mean for the first question is 1.0 because everyone responded with a "1" (Yes). The variance equals $\{$ (\# of responses * Sum of Squares) minus (Total * Total) $\} /\{\#$ of responses * (\# of responses -1$)\}$. The standard deviation equals the square root of the variance. 


\begin{tabular}{|c|c|c|c|c|c|}
\hline Question & Response Selections & $\begin{array}{c}\text { Result } \\
(\%)\end{array}$ & Mean & Variance & $\begin{array}{l}\text { Standard } \\
\text { Deviation }\end{array}$ \\
\hline \multirow{2}{*}{$\begin{array}{l}\text { I understand that the } \\
\text { survey is anonymous. }\end{array}$} & 1) Yes & 100 & \multirow{2}{*}{1.0} & \multirow{2}{*}{0.0} & \multirow{2}{*}{0.0} \\
\hline & 2 ) No & 0 & & & \\
\hline \multirow{3}{*}{$\begin{array}{l}\text { What level student are } \\
\text { you? }\end{array}$} & 1) Junior & 0 & \multirow{3}{*}{2.0} & \multirow{3}{*}{0} & \multirow{3}{*}{0} \\
\hline & 2 ) Senior & 100 & & & \\
\hline & 3) Graduate & 0 & & & \\
\hline \multirow{3}{*}{ What is your major? } & $\begin{array}{l}\text { 1) Mechanical } \\
\text { Engineering }\end{array}$ & 100 & \multirow{3}{*}{1} & \multirow{3}{*}{0} & \multirow{3}{*}{0} \\
\hline & $\begin{array}{l}\text { 2) Aeronautical } \\
\text { Engineering }\end{array}$ & 0 & & & \\
\hline & 3) Other & 0 & & & \\
\hline \multirow{2}{*}{ What is your sex? } & 1) Male & 86 & \multirow{2}{*}{1.14} & \multirow{2}{*}{0.12} & \multirow{2}{*}{0.35} \\
\hline & 2) Female & 14 & & & \\
\hline \multirow{5}{*}{ Marital Status } & 1) Single & 84 & \multirow{5}{*}{1.69} & \multirow{5}{*}{1.26} & \multirow{5}{*}{1.12} \\
\hline & 2) Married & 14 & & & \\
\hline & 3) Divorced & 2 & & & \\
\hline & 4) Widow & 0 & & & \\
\hline & 5) Widower & 0 & & & \\
\hline \multirow{4}{*}{$\begin{array}{l}\text { How many dependent } \\
\text { children at home? }\end{array}$} & 1) None & 89 & \multirow{4}{*}{1.11} & \multirow{4}{*}{0.11} & \multirow{4}{*}{0.10} \\
\hline & 2) 1 to 2 & 11 & & & \\
\hline & 3) 3 to 5 & 0 & & & \\
\hline & 4) More than 5 & 0 & & & \\
\hline
\end{tabular}

Table 1. Student Demographics. All students were seniors majoring in mechanical engineering. The great majority was male, single and had no children.

The mid-semester survey also considered student activities. These results are seen in Table 2 . The class discussion seemed to indicate that one of the primary issues was a lack of time to devote to the class. This was mentioned often, both explicitly and implicitly. Table 2 displays this evidence. 


\begin{tabular}{|c|c|c|c|c|c|}
\hline \begin{tabular}{|l|} 
Question \\
$\begin{array}{l}\text { Average hours of sleep } \\
\text { each night. }\end{array}$ \\
\end{tabular} & Response Selections & \multirow{2}{*}{$\begin{array}{l}\text { Result } \\
(\%) \\
88\end{array}$} & Mean & Variance & $\begin{array}{l}\text { Standard } \\
\text { Deviation }\end{array}$ \\
\hline \multirow{3}{*}{$\begin{array}{l}\text { Average hours of sleep } \\
\text { each night. }\end{array}$} & \begin{tabular}{|l|} 
1) Less than 7 \\
\end{tabular} & & \multirow{3}{*}{1.12} & \multirow{3}{*}{0.11} & \multirow{3}{*}{0.33} \\
\hline & $\begin{array}{l}\text { 2) More than } 7 \text { and less } \\
\text { than } 10\end{array}$ & 12 & & & \\
\hline & 3) More than 10 & 0 & & & \\
\hline \multirow{4}{*}{$\begin{array}{l}\text { Average hours a week } \\
\text { spent on family activities }\end{array}$} & 1) None & 23 & \multirow{4}{*}{2.32} & \multirow{4}{*}{1.01} & \multirow{4}{*}{1.00} \\
\hline & 2) 1 to 4 & 39 & & & \\
\hline & 3) 5 to 9 & 23 & & & \\
\hline & 4) More than 9 & 16 & & & \\
\hline \multirow{4}{*}{$\begin{array}{l}\text { How many paying jobs do } \\
\text { you have? }\end{array}$} & 1) None & 21 & \multirow{4}{*}{1.95} & \multirow{4}{*}{0.44} & \multirow{4}{*}{0.67} \\
\hline & 2) One & 67 & & & \\
\hline & 3) Two & 9 & & & \\
\hline & 4) Three or more & 4 & & & \\
\hline \multirow{2}{*}{$\begin{array}{l}\text { Will one of your jobs likely } \\
\text { lead to an engineering } \\
\text { position? }\end{array}$} & 1) Yes & 53 & \multirow[b]{2}{*}{1.47} & \multirow[b]{2}{*}{0.25} & \multirow[b]{2}{*}{0.50} \\
\hline & 2) No & 47 & & & \\
\hline \multirow[t]{6}{*}{$\begin{array}{l}\text { Average hours per week } \\
\text { spent on your job(s)? }\end{array}$} & 1) None & 18 & \multirow{6}{*}{3.49} & \multirow{6}{*}{2.29} & \multirow{6}{*}{1.51} \\
\hline & 2) Less than 10 & 5 & & & \\
\hline & $\begin{array}{l}\text { 3) More than } 10 \text { less than } \\
20\end{array}$ & 19 & & & \\
\hline & $\begin{array}{l}\text { 4) More than } 20 \text { and less } \\
\text { than } 30\end{array}$ & 37 & & & \\
\hline & $\begin{array}{l}\text { 5) More than } 30 \text { less than } \\
40\end{array}$ & 11 & & & \\
\hline & 6) More than 40 & 11 & & & \\
\hline
\end{tabular}

Table 2. Student Activities, Part 1 


\begin{tabular}{|c|c|c|c|c|c|}
\hline Question & Response Selections & $\begin{array}{c}\text { Result } \\
(\%)\end{array}$ & Mean & Variance & $\begin{array}{c}\text { Standard } \\
\text { Deviation }\end{array}$ \\
\hline \multirow{4}{*}{$\begin{array}{l}\text { How many course hours } \\
\text { are you taking this } \\
\text { semester? }\end{array}$} & 1) 1 to 3 & 16 & \multirow{4}{*}{2.61} & \multirow{4}{*}{0.78} & \multirow{4}{*}{0.88} \\
\hline & 2) 4 to 9 & 18 & & & \\
\hline & 3) 10 to 15 & 56 & & & \\
\hline & 4) 15 or more & 11 & & & \\
\hline \multirow{4}{*}{$\begin{array}{l}\text { How many clock hours per } \\
\text { week in community } \\
\text { activities? }\end{array}$} & 1)None & 47 & \multirow{4}{*}{1.67} & \multirow{4}{*}{0.58} & \multirow{4}{*}{0.76} \\
\hline & 2) 1 to 4 & 42 & & & \\
\hline & 3) 5 to 9 & 7 & & & \\
\hline & 4) More than 9 & 4 & & & \\
\hline \multirow{4}{*}{$\begin{array}{l}\text { How many hours per week } \\
\text { do you spend studying for } \\
\text { this class? }\end{array}$} & 1) None & 0 & \multirow{4}{*}{2.95} & \multirow{4}{*}{0.69} & \multirow{4}{*}{0.83} \\
\hline & 2) 1 to 4 & 37 & & & \\
\hline & 3) 5 to 9 & 32 & & & \\
\hline & 4) More than 9 & 32 & & & \\
\hline \multirow{4}{*}{$\begin{array}{l}\text { How many hours per week } \\
\text { do you spend studying for } \\
\text { all your other classes? }\end{array}$} & 1) None & 5 & \multirow{4}{*}{2.77} & \multirow{4}{*}{0.79} & \multirow{4}{*}{0.89} \\
\hline & 2) 1 to 4 & 37 & & & \\
\hline & 3) 5 to 9 & 33 & & & \\
\hline & 4) More than 9 & 25 & & & \\
\hline \multirow{4}{*}{$\begin{array}{l}\text { How many hours per week } \\
\text { on relaxation and } \\
\text { entertainment? }\end{array}$} & 1) None & 9 & \multirow{4}{*}{2.25} & \multirow{4}{*}{0.51} & \multirow{4}{*}{0.71} \\
\hline & 2) 1 to 4 & 65 & & & \\
\hline & 3) 5 to 9 & 19 & & & \\
\hline & 4) More than 9 & 7 & & & \\
\hline \multirow{4}{*}{$\begin{array}{l}\text { How many hours a day do } \\
\text { you spend on your cell } \\
\text { phone? }\end{array}$} & 1) None & 27 & \multirow{4}{*}{1.84} & \multirow{4}{*}{0.46} & \multirow{4}{*}{0.68} \\
\hline & 2) 1 to 4 & 68 & & & \\
\hline & 3) 5 to 9 & 0 & & & \\
\hline & 4) More than 9 & 5 & & & \\
\hline \multirow{4}{*}{$\begin{array}{l}\text { How many hours a day do } \\
\text { you spend on } \\
\text { transportation? }\end{array}$} & 1) None & 14 & \multirow{4}{*}{1.88} & \multirow{4}{*}{0.15} & \multirow{4}{*}{0.38} \\
\hline & 2) 1 to 4 & 84 & & & \\
\hline & 3) 5 to 9 & 2 & & & \\
\hline & 4) More than 9 & 0 & & & \\
\hline
\end{tabular}

Table 2. Student Activities, Part 2

Most students reported getting less than seven hours of sleep a day, and most (81\%) worked; $60 \%$ worked more than 20 hours a week. The majority of the students held at least one job. Over $50 \%$ of these jobs had the potential to lead to a full time engineering position after graduation. Some of the students (13\%) had two or more jobs. Furthermore, two-thirds were taking ten or more class hours. Almost three-quarters reported spending at least an hour a day on their cell phone. Slightly over a third reported studying less than five hours a week on this course.

A possible conclusion from the survey data was that students had taken on more responsibilities than they could adequately accommodate. Good part-time jobs were available locally because 
the university was located in a high technology town. Thus, several students revealed in the survey that they were getting less than seven hours of sleep, were working 20 hours or more a week, and were also enrolled as a full-time student. Thus, they complained about the class requiring too much time.

\section{Final Class Survey}

Students responded satisfactorily to the course revisions and the class was completed on that format. A survey was taken at the end of the semester to determine students' thoughts about the flipped classroom; specifically did the majority of the students want the flipped classroom ended. The survey included both selected response items and open response items to differentiate what students liked and disliked about the flipped classroom approach. 


\begin{tabular}{|c|c|c|c|c|c|}
\hline Question & Response Selections & $\begin{array}{c}\text { Result } \\
(\%)\end{array}$ & Mean & Variance & $\begin{array}{c}\text { Standard } \\
\text { Deviation }\end{array}$ \\
\hline \multirow{5}{*}{$\begin{array}{l}\text { I want to be notified } \\
\text { before registration if the } \\
\text { class is going to be } \\
\text { flipped. }\end{array}$} & 1) Strongly Agree & 88 & \multirow{5}{*}{1.15} & \multirow{5}{*}{0.21} & \multirow{5}{*}{0.46} \\
\hline & 2) Agree & 8 & & & \\
\hline & $\begin{array}{l}\text { 3) Neither Agree nor } \\
\text { Disagree }\end{array}$ & 4 & & & \\
\hline & 4) Disagree & 0 & & & \\
\hline & 5) Strongly Disagree & 0 & & & \\
\hline \multirow{5}{*}{$\begin{array}{l}\text { I liked the student } \\
\text { problem solving and } \\
\text { lecture method used in } \\
\text { the second half of the } \\
\text { semester better than the } \\
\text { purely problem solving } \\
\text { method that was used in } \\
\text { the first half of the } \\
\text { semester. }\end{array}$} & 1) Strongly Agree & 61 & \multirow{5}{*}{1.69} & \multirow{5}{*}{1.26} & \multirow{5}{*}{1.12} \\
\hline & 2) Agree & 25 & & & \\
\hline & $\begin{array}{l}\text { 3) Neither Agree nor } \\
\text { Disagree }\end{array}$ & 4 & & & \\
\hline & 4) Disagree & 4 & & & \\
\hline & 5) Strongly Disagree & 6 & & & \\
\hline \multirow{5}{*}{$\begin{array}{l}\text { The flipped classroom } \\
\text { approach used the second } \\
\text { half of the semester } \\
\text { makes it easier to } \\
\text { understand course content } \\
\text { than a traditional lecture } \\
\text { approach. }\end{array}$} & 1) Strongly Agree & 6 & \multirow{5}{*}{3.52} & \multirow{5}{*}{1.59} & \multirow{5}{*}{1.26} \\
\hline & 2) Agree & 19 & & & \\
\hline & $\begin{array}{l}\text { 3) Neither Agree nor } \\
\text { Disagree }\end{array}$ & 21 & & & \\
\hline & 4) Disagree & 25 & & & \\
\hline & 5) Strongly Disagree & 29 & & & \\
\hline \multirow{5}{*}{$\begin{array}{l}\text { The traditional classroom } \\
\text { approach would help me } \\
\text { learn the material better } \\
\text { than a flipped classroom } \\
\text { approach. }\end{array}$} & 1) Strongly Agree & 40 & \multirow{5}{*}{2.00} & \multirow{5}{*}{1.14} & \multirow{5}{*}{1.07} \\
\hline & 2) Agree & 33 & & & \\
\hline & $\begin{array}{l}\text { 3) Neither Agree nor } \\
\text { Disagree }\end{array}$ & 15 & & & \\
\hline & 4) Disagree & 10 & & & \\
\hline & 5) Strongly Disagree & 2 & & & \\
\hline
\end{tabular}

Table 3. End of Semester Survey, Part 1. This survey showed that the majority of the students did not want a flipped classroom approach to be used. This was clear regardless of the way the question was stated. 


\begin{tabular}{|c|c|c|c|c|c|}
\hline Question & Response Selections & $\begin{array}{c}\text { Result } \\
(\%)\end{array}$ & Mean & Variance & $\begin{array}{c}\text { Standard } \\
\text { Deviation }\end{array}$ \\
\hline \multirow{5}{*}{$\begin{array}{l}\text { I prefer a traditional } \\
\text { classroom over a flipped } \\
\text { classroom. }\end{array}$} & 1) Strongly Agree & 58 & \multirow{5}{*}{1.65} & \multirow{5}{*}{0.78} & \multirow{5}{*}{0.88} \\
\hline & 2) Agree & 23 & & & \\
\hline & $\begin{array}{l}\text { 3) Neither Agree nor } \\
\text { Disagree }\end{array}$ & 15 & & & \\
\hline & 4) Disagree & 4 & & & \\
\hline & 5) Strongly Disagree & 0 & & & \\
\hline \multirow{5}{*}{$\begin{array}{l}\text { I like learning lecture } \\
\text { materials on my own time } \\
\text { outside of class }\end{array}$} & 1) Strongly Agree & 10 & \multirow{5}{*}{3.48} & \multirow{5}{*}{1.63} & \multirow{5}{*}{1.28} \\
\hline & 2) Agree & 12 & & & \\
\hline & $\begin{array}{l}\text { 3) Neither Agree nor } \\
\text { Disagree }\end{array}$ & 27 & & & \\
\hline & 4) Disagree & 25 & & & \\
\hline & 5) Strongly Disagree & 27 & & & \\
\hline \multirow{5}{*}{$\begin{array}{l}\text { I like being called upon to } \\
\text { publicly do a homework } \\
\text { problem in class. }\end{array}$} & 1) Strongly Agree & 13 & \multirow{5}{*}{2.85} & \multirow{5}{*}{1.15} & \multirow{5}{*}{1.07} \\
\hline & 2) Agree & 25 & & & \\
\hline & $\begin{array}{l}\text { 3) Neither Agree nor } \\
\text { Disagree }\end{array}$ & 25 & & & \\
\hline & 4) Disagree & 37 & & & \\
\hline & 5) Strongly Disagree & 0 & & & \\
\hline \multirow{5}{*}{$\begin{array}{l}\text { I will attend a course in } \\
\text { which the flipped } \\
\text { classroom is used for } \\
\text { every class hour. }\end{array}$} & 1) Strongly Agree & 2 & \multirow{5}{*}{4.29} & \multirow{5}{*}{0.88} & \multirow{5}{*}{0.94} \\
\hline & 2) Agree & 2 & & & \\
\hline & $\begin{array}{l}\text { 3) Neither Agree nor } \\
\text { Disagree }\end{array}$ & 15 & & & \\
\hline & 4) Disagree & 27 & & & \\
\hline & 5) Strongly Disagree & 54 & & & \\
\hline
\end{tabular}

Table 3. End of Semester Survey, Part 2

Analysis of the open response questions revealed students' likes and dislikes of the flipped classroom approach used in the heat transfer course. There were 48 responses for the open-ended response question about, "What did you like about the flipped classroom approach used in the heat transfer class?" The topic most often mentioned was related to presenting the homework in class. Twenty-five percent of the responses were positive about presenting homework in class. In addition, $17 \%$ of the responses felt it made them more motivated to do the homework. Other topics were only mentioned once or twice in the responses.

Of the 49 responses for the open-ended response question, "What did you dislike about the flipped classroom approach used in the heat transfer class?” forty-nine percent did not like being graded on their presentations in class. Twenty-two percent did not like having no lectures in the 
first half of the semester, and $17 \%$ felt it took too much time to prepare for the class. Four percent mentioned they did not like being called on to speak in public.

\section{Lessons Learned}

This experiment has demonstrated that a senior level undergraduate engineering heat transfer course could be implemented using a flipped classroom approach. The professor continued to value the flipped classroom approach to teaching, but admitted that there were some lessons learned during the flipping and revising of the course. We share those lessons learned in this section. Specifically, we discuss student perceptions of a flipped classroom approach, recording participation and attendance in a flipped classroom, and future design features.

\section{Student Perceptions of a Flipped Classroom Approach}

Unlike some of the research on flipped classrooms ${ }^{9}$, the students in this study indicated being dissatisfied with the flipped classroom approach. Survey data suggests that this was partially because students had not allotted sufficient time to complete the lecture and homework problems outside of class with the plethora of other responsibilities they had. Open-ended responses further highlighted that students did not enjoy being graded on homework presentations and wanted to learn the material from an expert in class versus through video lectures. The students voiced mid semester that only having lectures online did not allow students to have real time dialogues with the professor and that the video did not provide real time feedback of student learning. 10

To address student time constraints, videos for the course could be specifically created for the flipped classroom that are shorter and more condensed, but even the shorter selected topic videos were not viewed by the majority of students in this study. Technology platforms could also be utilized to merge formative assessment questions and video lectures ${ }^{11}$ to collect data about how students are making sense of the content and what questions or misconceptions the professor might need to address at the beginning of the next class. This might also provide students with more of a sense of professor-student interaction.

Recording Participation and Attendance in a Flipped Classroom

Class participation and attendance are important. Attending and engaging in class is similar to professional career skills that employers value. Class participation also supports the professor's ability to formatively assess students' understanding of content through questioning, and use student responses to guide instruction. ${ }^{12}$ In addition, students learn from each other and from the professor. So, recording participation and attendance, and providing a grade incentive was worthwhile in this case.

This study demonstrates how participation can be recorded through homework presentations. Furthermore, student involvement in presentations can be increased when the problems are 
divided across multiple random presenters. This instructional practice required some planning prior to class, while also effectively and efficiently involving students. Another benefit of dividing the lengthy questions for multiple presenters was that it required students to follow the presentation in case their name was called upon next. After the class ended, students confessed that they sometimes did not do the homework and instead took the chance that they would not be called on in class. With multiple presenters per class though, they often got caught.

The sign-in sheet was less effective for recording student attendance in this study because students forged each other's names. A better option might be to use the feature in the university's web service portal that allows electronic recording of attendance. With this attendance process, the student would need access to the web at the beginning of class. Students would then log in and provide a keyword to sign into the class. This requires a computer at every desk or that everyone has access to a digital device. Either way, class attendance will still receive course participation credit whether this method turns out to be feasible or if a sign-up sheet is still used.

\section{Future Design Features}

The following design features from this study are offered for other professors exploring the possibilities of flipping a course. Furthermore, the professor utilized these design features in the next semester's heat transfer course, which was also flipped.

1) If possible before registration, notify the students that the class will be taught in a flipped manner.

2) Understand students have many commitments, including this class. Be explicit about your expectations.

3) Explain how the class activities will help them in their careers.

4) Explain and start the flipped classroom process during the first class. But, do not start grading the students until the second class.

5) Randomly pick a student to present her/his solution to an assigned problem. She/he is expected to work the problems before class.

6) Maintain control of the front of the room. Students speak at their seat.

7) Encourage their efforts. This may be the first time students have spoken in front of a group.

8) Record the student's important points even if they are wrong.

9) Use questions to evoke comments from the class about material on the board.

10) Interact with the students to obtain clarity.

11) Interject additional insights based on your experience.

12) Use one hour for presentations and 30 minutes for live lectures.

13) Make the lectures clear and succinct.

14) Before class, select student presenters and their portion of a problem. But, do not notify the students ahead of time. 
15) Record your evaluation of her/his presentation. If she/he is not prepared, she/he loses points. If she/he does well she/he gains points.

16) Collect and grade the homework of the students that presented. This assures they are actually using the required format and have, at least, transcribed the solution in their own handwriting.

17) Learn all of the students' names before class starts. Pictures are available from the university.

18) Have the presentations and submitted written homework be a part of the final grade.

The subsequent class using these procedures was being taught the following semester and was still underway when this paper was written. The results of that experience will be shared after that class is complete.

\section{Bibliography}

1) R. Elliott, "Analysis of Student Perceptions and Behaviors in a Flipped Classroom Undergraduate Information Technology Course.” $121^{\text {st }}$ ASEE Annual Conference \& Exposition June 15 - 18, 2014 paper ID \# 8863

2) S. Chetcuti, H. Thomas, and B. Pafford, "Flipping the Engineering Classroom: Results and Observations with Non-Engineering Students”, $121^{\text {st }}$ ASEE Annual Conference \& Exposition June 15- 18, 2014, paper ID \# 10923

3) J. Bishop and M. Verleger, “The Flipped Classroom: A Survey of the Research” $120^{\text {th }}$ ASEE Annual Conference \& Exposition, June 23-26, 2013, Paper ID \# 6219

4) R. Haddad and Y. Kalaani, “A Novel Peer-Assisted Hybrid Flipped Classroom Model Using Online Discussion” 122 ASEE Annual Conference and Exposition, June 14-17, 2015, Paper ID \# 13620

5) L. Lee, R. Hackett, and H. Estrada, "Evaluation of a Flipped Classroom in Mechanics of Materials”, 122 ASEE Annual Conference and Exposition, June 14-17, 2015, Paper ID \# 11392

6) K. Sharpe, Ph. D., University of Virginia, Darden School of Business) personal communication.

7) S. Chetcuti, H.Thomas, and B. Pafford, "Flipping the Engineering Classroom, Lessons Learned in the Creation, Production and Implementation”, page 7, Fall 2013 Middle Atlantic Section Proceedings Archives, ASEE

8) T. L. Bergman, A. S. Lavine, F. P. Incropera, and D. P. Dewitt, "Fundamentals of Heat and Mass Transfer" $7^{\text {th }}$ ed.; Pg 38, J. Wiley and Sons. (C2011, 2007, 2002

9) B. Kerr, “The flipped classroom in engineering education”, Proceedings of 2015 International Conference on Interactive Collaborative Learning, September 20-24, 2015. Paper \# 978-1-4799-8706-1

10) R. Olson, "Flipping Engineering Probability and Statistics - Lessons Learned for Faculty Considering the Switch.” $121^{\text {st }}$ ASEE Annual Conference \& Exposition June 15- 18, 2014, paper ID \#10166

11) J. W. Stigler, E. H. Geller, and K. B. Givvin, “Zaption: A Platform to Support Teaching, and Learning about Teaching, with Video”, Journal of e-Learning and Knowledge Society, Vol 11\# 2, pps. 13 - 25, 2015

12) P. Black and D. Wiliam, "Inside the black box: Raising Standards through Classroom Assessment”, Phi Delta Kappa, pps. 1-13, October, 1998 


\section{Biographical Information}

Francis C. Wessling holds a B.S.M.E. from Washington University, an M.S.M.E. from the University of New Mexico, and the Ph. D. in Mechanical Engineering from the University of Minnesota. He is a professor in the Department of Mechanical and Aerospace Engineering, a Fellow of the American Society of Mechanical Engineers, and a registered professional engineer in the State of Alabama.

Sarah A. Roller is an Assistant Professor in the Department of Curriculum and Instruction at the University of Alabama in Huntsville. She received her Ph.D. in curriculum, teaching, and educational policy from Michigan State University. Her research interests include teacher preparation and mentoring practices, research-based instructional strategies for teaching mathematics and STEM education, and teacher development. 